François Donati PHD MD FRCPC, Jocelyne Lahoud MD, David McCready, David R. Bevan MB MRCP FFarCs

\title{
Neostigmine, pyridostigmine and edrophonium as antagonists of deep pancuronium blockade
}

The effects of non-depolanizing muscle relaxants on neuro-

To compare the ability of equipotent doses of neostigmine, pyridostigmine and edrophonium to antagonize intense pancuronium neuromuscular blockade, one hundred and twenty ASA physical status I or II patients scheduled for elective surgery received $0.06 \mathrm{mg} \mathrm{kg}^{-1}$ pancuronium during a thiopentonenitrous oxide-enflurane anaesthetic. Train-of-four stimulation was applied every $12 \mathrm{~s}$ and the force of contraction of the adductor policis muscle was recorded. In the first 60 patients, spontaneous recovery was allowed until ten per cent of initial first twitch height. Then neostigmine $(0.005,0.01,0.02$ or 0.05 $\left.\mathrm{mg} \cdot \mathrm{kg}^{-1}\right)$, pyridostigmine $\left(0.02,0.04,0.1\right.$ or $\left.0.2 \mathrm{mg} \cdot \mathrm{kg}^{-1}\right)$, or edrophonium $\left(0.1,0.2,0.4\right.$ or $\left.1 \mathrm{mg} \cdot \mathrm{kg}^{-1}\right)$ was injected by random allocation. Dose-response relationships were established from the measurement of first twitch height (TI) ten minutes later. From these, neostigmine, 0.04 and $0.08 \mathrm{mg} \cdot \mathrm{kg}^{-1}$ was found to be equipotent to pyridostigmine, 0.2 and $0.38 \mathrm{mg} \cdot \mathrm{kg}^{-1}$, and edrophonicm, 0.54 and $1.15 \mathrm{mg} \cdot \mathrm{kg}^{-1}$, respectively. These doses were given by random allocation to the next 60 patients, but at one per cent spontaneous recovery. Neostigmine, $0.04 \mathrm{mg}^{-\mathrm{kg}^{-1}}$, produced a TI of $73 \pm 4$ per cent (mean \pm SEM), and a train-of-four ratio (TOF) of $39 \pm 3$ per cent. This was significantly greater than with pyridostigmine, $0.2 \mathrm{mg} \cdot \mathrm{kg}^{-3}$ $(T 1=50 \pm 6$ percent; $T O F=25 \pm 3$ per cent $)$, and edrophonium, $0.54 \mathrm{mg} \cdot \mathrm{kg}^{-1}(T l=54 \pm 3$ per cent; TOF $=17 \pm 2$ per cent $)$. With the higher doses, neostigmine, $0.08 \mathrm{mg} \cdot \mathrm{kg}^{-1}$. produced more recovery of $T 1(83=3$ per cenl) and TOF $(45 \pm 3$ per cent $)$ than either pyridostigmine, $0.38 \mathrm{mg} \cdot \mathrm{kg}^{-1}(T 1=74 \pm 3$ percent $)$ or edrophonium, $1.15 \mathrm{mg} \cdot \mathrm{kg}^{-1}(T I=71 \pm 4$ per cent; $T O F=$ $30 \pm 3$ per cent). It is concluded that neostigmine is more effective than the other wo agents in the antagonism of deep pancuronium blockade.

\section{Key words}

ANTAGONISTS, NEUROMUSCULAR RELAXANTS: neostigmine, pyridostigmine, edrophonium; NEUROMUSCULAR RELAXANTS: pancuronium.

From the Department of Anaesthesia, Royal Victoria Hospital and McGill University, Montreal, Quebec.

Address correspondence to: Dr. F. Donati, Department of Anaesthesia, Royal Victoria Hospital, 687 Pine Avenue West, Montreal, Quebec, H3A 1A1. muscular function are usually reversed with neostigmine, pyridostigmine or edrophonium. ${ }^{1,2}$ The efficacy of these agents is altered considerably by the intensity of blockade at the time they are administered. ${ }^{3-5}$

Edrophonium, $0.5 \mathrm{mg} \cdot \mathrm{kg}^{-1}$, was found to be less effective than neostigmine, $0.04-0.05 \mathrm{mg} \cdot \mathrm{kg}^{-1}$, in the antagonism of deep atracurium, vecuronium, or pancuronium blockade. ${ }^{4,5}$ These comparisons were based on a neostigmine: edrophonium potency ratio of 12 determined by Cronnelly et $a l^{2}{ }^{2}$ during a stable infusion of d-tubocurarine. However, after neuromuscular blockade produced by pancuronium, the edrophonium: neostigmine potency ratio was found to be $16 .{ }^{6}$ Therefore, it is possible that the dose of edrophonium used in the studies of deep blockade antagonism, was too low. Furthermore, the efficacy of pyridostigmine in the antagonism of profound neuromuscular blockade has not been evaluated.

This study was designed to determine equipotent doses for the reversal agents when administered at 90 per cent pancuronium blockade, and then to give them at 99 per cent blockade. Dose-response curves were established for neostigmine, pyridostigmine and edrophonium at ten per cent first twitch height spontaneous recovery. From these, equipotent doses were calculated and then given in the same clinical conditions, but at a greater degree of neuromuscular block (one per cent first twitch height recovery). In all cases, recovery was assessed at a fixed, clinically relevant time (10 $\mathrm{min})$ after injection of the reversal agent.

\section{Methods}

The protocol was approved by the Hospital Ethics Committee. One hundred and twenty ASA physical status I or II adults, aged 18-75 years, were studied during elective surgical procedures of at least $90 \mathrm{~min}$ duration. Patients with hepatic, renal or neuromuscular disease were excluded, as were those with electrolyte abnormality and those taking any medication known or suspected of interfering with neuromuscular function. Premedication 
consisted of atropine, $6-10 \mu \mathrm{g} \cdot \mathrm{kg}^{-1}$, or glycopyrolate, 3-5 $\mu \mathrm{g} \cdot \mathrm{kg}^{-1}$ and morphine, $0.1 \mathrm{mg} \cdot \mathrm{kg}^{-1}$ or meperidine, $1 \mathrm{mg} \cdot \mathrm{kg}^{-1}$, given intramuscularly $1 \mathrm{~h}$ before the scheduled start of the procedure. On arrival in the operating room, the patient's ECG and blood pressure were monitored. Anaesthesia was induced with thiopentone, 3-5 $\mathrm{mg} \cdot \mathrm{kg}^{-1}$, and maintained with nitrous oxide, 70 per cent, and enflurane, 0.5-1.5 per cent inspired, in oxygen.

The ulnar nerve was stimulated supramaximally at the elbow with square pulses of $0.2 \mathrm{~ms}$ in duration, delivered at a frequency of $2 \mathrm{~Hz}$ for $2 \mathrm{~s}$ (train-of-four) and repeated every $12 \mathrm{~s}$. The hand and forearm were immobilized in a splint and the force of contraction of the adductor pollicis muscle was measured with a force-displacement transducer (Grass FT-10), and recorded on paper. A baseline was established after induction of anaesthesia, while the patient was manually ventilated via a mask. Then, pancuronium, $0.06 \mathrm{mg} \cdot \mathrm{kg}^{-1}$, was given intravenously. If necessary, increments of $0.5 \mathrm{mg}$ were given until development of 100 per cent blockade. Tracheal intubation was performed when maximum blockade was attained. The patients were ventilated using a Mapleson D circuit with a fresh gas flow of $70 \mathrm{ml} \cdot \mathrm{kg} \cdot \mathrm{min}^{-1}$. After tracheal intubation, the inspired enflurane concentration was kept constant. Intermittent doses of fentanyl, $1-2 \mu \mathrm{g} \cdot \mathrm{kg}^{-1}$, were administered if required.

In the first part of the study, the neuromuscular blockade in 60 patients was allowed to recover to ten per cent of first twitch height. At that time, they were given either neostigmine, $0.005,0.01,0.02$, or $0.05 \mathrm{mg} \cdot \mathrm{kg}^{-1}$, or pyridostigmine, $0.02,0.04,0.1$ or $0.2 \mathrm{mg} \cdot \mathrm{kg}^{-1}$, or edrophonium, $0.1,0.2,0.4$ or $1 \mathrm{mg} \cdot \mathrm{kg}^{-1}$, by random allocation. An appropriate dose of atropine $0.3-1.5 \mathrm{mg}$ was also injected. No further reversal agent was administered for at least $10 \mathrm{~min}$. Dose-response curves were constructed using first twitch height and train-of-four ratio measured $10 \mathrm{~min}$ after the reversal agent was given. The logit transformation of first twitch height was plotted against the logarithm of dose. ${ }^{7}$ Equipotent doses for neostigmine $0.04 \mathrm{mg} \cdot \mathrm{kg}^{-1}$ (lower dose) and $0.08 \mathrm{mg} \cdot \mathrm{kg}^{-1}$ (higher dose) were determined.

In the second part of the study, 60 patients were allowed to recover spontaneously only to one per cent of first twitch height ( 99 per cent blockade), instead of ten per cent ( 90 per cent blockade). Then, either neostigmine, pyridostigmine or edrophonium was injected, by random allocation, in a dose found to be equipotent to neostigmine, 0.04 or $0.08 \mathrm{mg} \cdot \mathrm{kg}^{-1}$, when given at ten per cent recovery. Neuromuscular monitoring was continued for at least $10 \mathrm{~min}$, at which time first twitch height and train-of-four ratio were recorded.

The results are expressed as mean \pm standard error of the mean (SEM), and compared using analysis of variance (ANOVA). When statistically significant with ANOVA, the Bonferroni correction was applied to Student's t test. ${ }^{8}$ A difference associated with a $p$ value $\leq 0.05$ was considered statistically significant.

\section{Results}

In the first part of the study, there were 27 males and 33 females. Mean age was $45 \pm 2$ years and mean weight was $69 \pm 2 \mathrm{~kg}$. The demographic data were very similar in the second part of the study; there were 30 males and 30 females, age was $46 \pm 2$ years and weight was $67 \pm 2 \mathrm{~kg}$.

Neostigmine, $0.04 \mathrm{mg} \cdot \mathrm{kg}^{-1}$, pyridostigmine, 0.2 $\mathrm{mg} \cdot \mathrm{kg}^{-1}$, and edrophonium $0.54 \mathrm{mg} \cdot \mathrm{kg}^{-1}$ were found to be equipotent. All three doses produced recovery of first twitch height to 80 per cent, ten minutes after administration, when injected at ten per cent spontaneous recovery. The train-of-four ratios corresponding to these doses were (mean \pm SE) $57 \pm 3$ per cent, $45=2$ per cent and $43 \pm 3$ per cent, respectively (ANOVA $p=0.004$ ). Neostigmine, $0.08 \mathrm{mg} \cdot \mathrm{kg}^{-1}$, pyridostigmine, $0.38 \mathrm{mg} \cdot \mathrm{kg}^{-1}$, and edrophonium, $1.15 \mathrm{mg} \cdot \mathrm{kg}^{-1}$ were found to be equipotent. They all produced a first twitch height of 89 per cent when given at ten per cent spontaneous receovery. The train-offour ratios were $74 \pm 4$ per cent, $58 \pm 2$ per cent and 57 \pm 3 per cent respectively (ANOVA $p=0.0005$ )

When given at one per cent spontaneous recovery, doses which were equipotent at ten per cent recovery produced different effects. As expected, edrophonium was rapid in onset and pyridostigmine was slow (Figure 1). Ten minutes after the administration of the reversal agent, neostigmine produced a better recovery than the other two drugs. With neostignine $0.04 \mathrm{mg} \cdot \mathrm{kg}^{-1}$, first twitch height was $73 \pm 4$ per cent, compared with $50 \pm 6$ per cent with pyridostigmine, $0.2 \mathrm{mg} \cdot \mathrm{kg}^{-1}$, and $54 \pm 3 \mathrm{per}$ cent with edrophonium, $0.54 \mathrm{mg} \cdot \mathrm{kg}^{-1}$ (ANOVA $\mathrm{p}=$ 0.003 ) (Figure 2). Train-of-four ratios were $39 \pm 3$ per cent, $25 \pm 3$ per cent and $17 \pm 2$ per cent for the three drugs respectively (ANOVA $p=0.00005$ ) (Figure 3). Using the Bonferroni correction, neostigmine was found to be more effective than either pyridostigmine or edrophonium in reversing first twitch height and train-offour ratio. For the higher doses of the reversal agents, neostigmine $0.08 \mathrm{mg} \cdot \mathrm{kg}^{-1}$, produced $83 \pm 3$ per cent recovery of first twitch, pyridostigmine, $0.38 \mathrm{mg} \cdot \mathrm{kg}^{-1}$, $74=3$ per cent, and edrophonium $1.15 \mathrm{mg} \cdot \mathrm{kg}^{-1}, 71 \pm 4$ per cent (ANOVA $p=0.03$ ) (Figure 2). The larger values obtained with neostigmine were statistically different from those of the other two agents. Corresponding train-of-four ratios were $46 \pm 3$ per cent, $38 \pm 4$ per cent and $30 \pm 3$ per cent (ANOVA $p=0.01$ ) (Figure 3). In this case, only the difference between neostigmine and edro- 


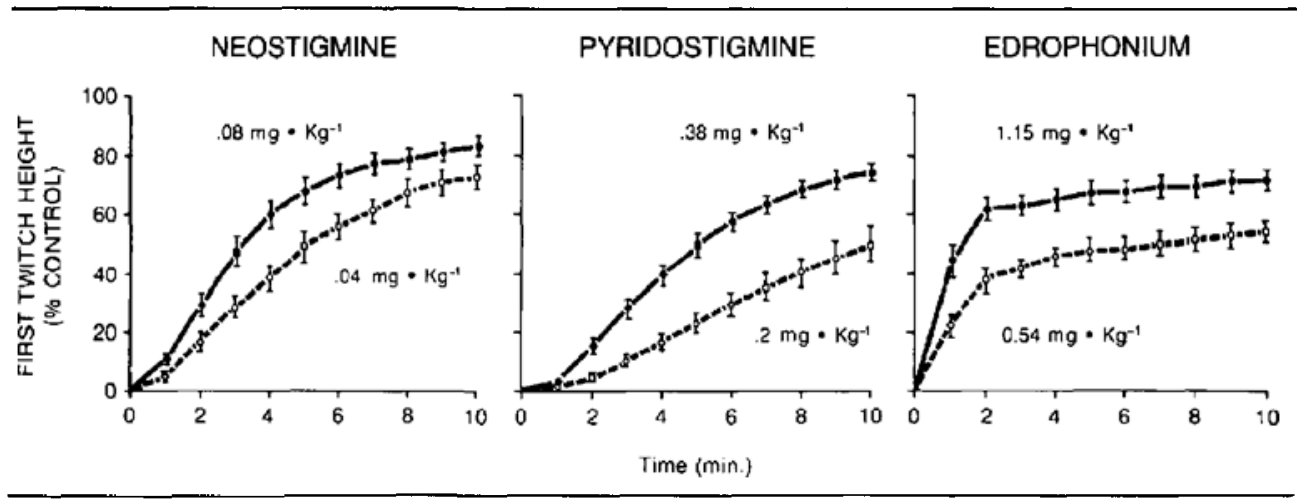

FIGURE I First twitch height versus time after the administration of the reversal agents, which were injected at one per cent spontaneous recovery.

phonium was statistically significant. None of the sixty patients studied had a train-of-four ratio greater than 70 per cent after $10 \mathrm{~min}$; the highest value was 61 per cent.

\section{Discussion}

This study demonstrated that profound pancuronium blockade is difficult to antagonize, even with large dases of reversal agents. However, in this situation, neostigmine appears to be superior to either pyridostigmine or edrophonium. The reversal drugs were first given at ten per cent spontancous recovery, in order to determine equipotent doses. Then, these doses were given under the same conditions, except that the intensity of neuromus-

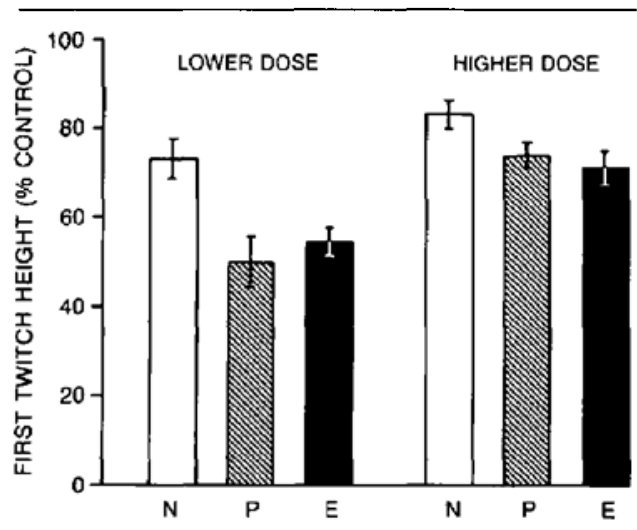

FIGURE2 First twitch height (per cent of control) 10 min after administration of neostigmine, $0.04 \mathrm{mg} \cdot \mathrm{kg}^{-1}$, pyridostigmine, $0.2 \mathrm{mg} \cdot \mathrm{kg}^{-1}$, or edrophonium, $0.54 \mathrm{mg} \cdot \mathrm{kg}^{-1}$ (luwer duse), or $0.08 \mathrm{mg} \cdot \mathrm{kg}^{-1}, 0.38$ $\mathrm{mg} \cdot \mathrm{kg}^{-1}$, or $1.15 \mathrm{mg} \cdot \mathrm{kg}^{-1}$, respectively (higher dose). Bars represent SEM. cular blockade was greater (one per cent spontaneous recovery). All responses were assessed ten minutes after the administration of the reversal drug. This approach ensures that other factors which may affect the potency of reversal drugs, such as the relaxant used, the method of administration, and the time until the response is assessed, do not play a role.

The lower doses chosen for the second part of the study (neostigmine $0.04 \mathrm{mg} \cdot \mathrm{kg}^{-1}$, pyridostigmine $0.2 \mathrm{mg} \cdot \mathrm{kg}^{-1}$, and edrophonium $0.54 \mathrm{mg} \cdot \mathrm{kg}^{-1}$ ) correspond to the doses used clinically, and were within the range of values which were administered previously to obtain dose-response curves. The higher doses were approximately twice as large (neostigmine $0.08 \mathrm{mg} \cdot \mathrm{kg}^{-1}$, pyridostigmine 0.38

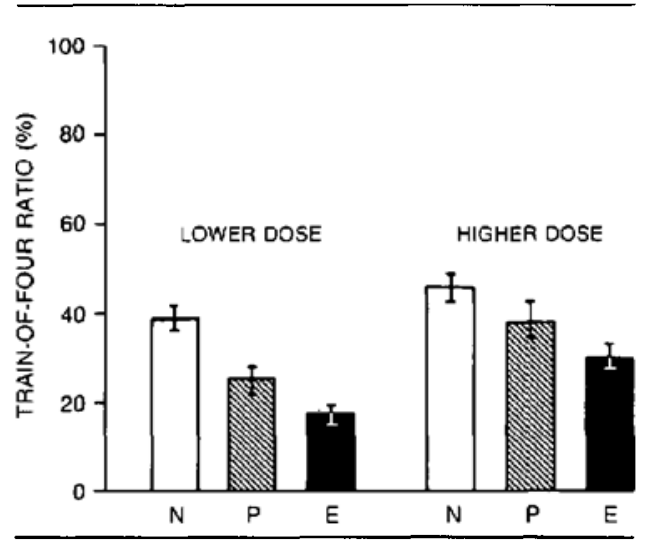

FIGURE 3 Train-of-four ratio $10 \mathrm{~min}$ after administration of neostigmine, $0.04 \mathrm{mg} \cdot \mathrm{kg}^{-1}$, pyridostigmine, $0.2 \mathrm{mg} \cdot \mathrm{kg}^{-1}$, or edrophonium, $0.54 \mathrm{mg} \cdot \mathrm{kg}^{-1}$ (lower dose), or $0.08 \mathrm{mg} \cdot \mathrm{kg}^{-1}, 0.38 \mathrm{mg} \cdot \mathrm{kg}^{-1}$, or $1.15 \mathrm{mg} \cdot \mathrm{kg}^{-1}$, respectively (higher dose). Bars represent SEM. 
$\mathrm{mg} \cdot \mathrm{kg}^{-1}$, and edrophonium $1.15 \mathrm{mg} \cdot \mathrm{kg}^{-1}$ ). Although they were outside the range of values tested in the first part of the study, a significant error in the estimate of these equipotent doses could not occur unless there were major enors in the estimate of the slope of the regression lines.

The dose-response curves obtained at ten per cent spontaneous recovery were not exactly parallel. As a result, the potency ratios depended on the dose chosen for comparison. For example, neostigmine, $0.04 \mathrm{mg} \cdot \mathrm{kg}^{-1}$ was 5 times as potent as pyridostigmine, and 13.5 times as potent as edrophonium. At a dose of $0.08 \mathrm{mg} \cdot \mathrm{kg}^{-1}$, neostigmine was 4.75 times as potent as pyridostigmine and 14.4 times as potent as edrophonium. These differences are small, and the potency ratios are similar to those reported during a constant infusion of d-tubocurarine. In this case, neostigmine was 4.35 times as potent as pyridostigmine, ${ }^{9}$ and 12 times as potent as edrophonium. ${ }^{2}$

This study supports earlier work which demonstrated that profound neuromuseular blockade was much more difficult to antagonize than less intense blockade. ${ }^{3,4,10}$ In this study, mean first twitch height and train-of-four ratio were much less if the reversal agent had been given at one per cent compared with ten per cent spontaneous recovery. In addition, the calculation of dose-response curves made it possible to test the hypothesis that edrophonium was less effective than neostigmine in the antagonism of intense blockade. Rupp et al. ${ }^{4}$ assumed that edrophonium had 1/12th the potency of neostigmine, based on data obtained with a constant infusion of d-tubocurarine, ${ }^{2}$ and found edrophonium $0.5 \mathrm{mg} \cdot \mathrm{kg}^{-1}$, less effective than neostigmine $0.04 \mathrm{mg} \cdot \mathrm{kg}^{-1}$, in the reversal of intense (two to ten per cent first twitch height) block. However, edrophonium, $1 \mathrm{mg} \cdot \mathrm{kg}^{-1}$, was found to be as effective as neostigmine, $0.04 \mathrm{mg} \cdot \mathrm{kg}^{-1}$. The results could be interpreted as being the consequence of a decreased effectivencss of edrophonium when given during intense blockade. Another explanation could be that the neostigmine: edrophonium potency ratio might be different if these drugs are given with a different relaxant (atracurium, pancuronium or vecuronium vs d-tubocurarine) and during the spontaneous recovery of the block instead of during a constant infusion. Our results suggest that with pancuronium, the neostigmine:edrophonium potency ratio might be slightly greater than $12(13-14$ in this study; 16 in another). ${ }^{6}$ However, even when given in doses which were equipotent at ten per cent spontaneous recovery, neostigmine was more effective than edrophonium in reversing 99 per cent blockade. The effectiveness of pyridostigmine in the reversal of deep blockade has not been evaluated before. The results of this study indicate that it is also less effective than neostigmine in this regard.

Neostigmine, pyridostigmine and edrophonium have actions other than inhibition of acetylcholinesterase. ${ }^{1,12}$ The relative importance of these actions is probably different for each drug, because the characteristics of block reversal are different. For example, the relationship between first twitch height and train-of-four ratio is not the same for all three agents. In this study, the train-offour ratio was greater with neostigmine than the other two agents when equipotent doses were given at ten per cent recovery. Pyridostigmine has been found to exhibit more fade than neostigmine, ${ }^{13}$ and this was also observed here. However, train-of-four fade has been reported to be less with edrophonium than neostigmine, at the same degree of first twitch depression. ${ }^{13,14}$ In this study, fade was greater with edrophonium, at 80 per cent and 89 per cent first twitch height. This apparent contradiction is probably due to the different conditions of the study. Jones et al. ${ }^{14}$ used edrophonium to reverse less intense blocks (mean first (witch height of 43 per cent) than in this study (one to ten per cent). In another study, edrophonium was given at ten per cent recovery of first twitch, and was found to exhibit less fade than neostigmine in the range 30-50 per cent of first twitch, but not in the 80-89 per cent range, corresponding to the doses used here. Thus, it appears that the relative importance of the train-of-four reversing properties of edrophonium is dose-related, being much less apparent when large doses are used to antagonize deep blockade. With the doses used in this study, neostigmine was the most effective in reversing train-of-four fade, and had the greatest effect on intense blockade. This suggests that effectiveness in reversing intense neuromuscular blockade might depend on the ability to reverse fade. Thus, it appears that the antagonism of the effect of neuromuscular blockers on the site of action associated with train-of-four fade (possibly presynaptic), ${ }^{15}$ is essential for an adequate reversal of intense blockade.

Clinically, adequate neuromuscular recovery (train-offour ratio greater than 70 per cent), ${ }^{16}$ cannot be achieved with usual doses of neostigmine, pyridostigmine or edrophonium given during 99 per cent pancuronium blockade, unless one is prepared to wait more than ten minutes. Thus, it is preferable to avoid profound neuromuscular blockade entirely. However, if such a situation arises, large doses of neostigmine $\left(0.08 \mathrm{mg} \cdot \mathrm{kg}^{-1}\right)$ are more likely to produce the desirable effect than pyridostigmine or edrophonium.

\section{References}

1 Ferguson A, Egerszegi P, Bevan DR. Neostigmine, pyridostigmine, and edrophonium as antagonists of pancuronium. Anesthesiology 1980; $53: 390-4$. 
2 Cronnelly $R$, Morris $R B$, Miller DR. Edrophonium: duration of action and atropine requirement in humans during halothane anesthesia. Anesthesiology 1982; 57: 261-6.

3 Katz $R \boldsymbol{L}$. Clinical neuromuscular pharmacology of pancuronium. Aresthesiology 1971:34: 550-6.

4 Rupp SM, McChristian JW. Miller RD, Toboada JA, Cronnelly $R$. Neostigmine and edrophonium antagonism of varying intensity neuromuscular blockade induced by atracurium, pancuronium or vecuronium Anesthesiology 1986; 64: $711-7$

5 Lavery GG, Mirakhur RK, Gibson FM. A comparison of edrophonium and neostigmine for the antagonism of atracurjum-induced neuromuscular block. Anesth Analg 1985; 64: 867-70.

6 Breen PJ, Doherty WG, Donati F, Bevan DR. The potencies of edrophonium and neostigmine as antagonists of pancuronium. Anaesthesia 1985; 40: 844-7.

7 Norman J. Drug receptor reaction. In "Pharmacokinetics of Anaesthesia." Prys-Roberts C, Hugg CC Jr (Eds). Oxford, Blackwell Scientific Publications, Oxford, 1984, pp 25-37.

8 Wallenstein S, Zucker LL, Fleiss $J L$. Some statistical methods useful in circulation research. Circ Res 1980; 47: $1-9$.

9 Miller RD, Van Nyhuis LS, Eger EI II, Vitez TS, Way WL. Comparative times to peak effect and durations of action of neostigmine and pyridostigmine. Anesthesiology $1974 ; 41: 27-33$

10 Hennart D, d'Hollander A, Plasman C, DeJonckheere $M$. Importance of the level of paralysis recovery for rapid antagonism of atracurium neuromuscular blockade with moderate doses of edrophonium. Anesthesiology 1986; 64: 384-7.

11 Riker WF, Okamoto MO. Pharmacology of motor nerve terminals. Ann Rev Pharmacol 1969; 9: 173-208.

12 Miyamoto $M D$. The actions of cholinergic drugs on motor nerve terminals. Pharmacol Rev 1978; 29: 221-47.

13 Donati F, Ferguson A, Bevan DR. Twitch depression and train-of-four ratio after antagonism of pancuronium with edrophoniurn, neostigmine, or pyridostigmine. Anesth Analg 1983; 62: 314-6

14 Jones RM, Pearce AC, Williams JP. Recovery characteristics following antagonism of atracurium with neostigmine or edrophonium. Br J Anaesth 1984; 56: 453-7.

15 Bowman WC. Prejunctional and postjunctional tholinoceptors at the neuromuscular junction. Anesth Anaig 1980; 59: 935-43.

16 Ali $H H$, Wilson RS, Savarese JJ, Kitz JL. The effect of tubocurarine on indirectly elicited train-of-four muscle response and respiratory measurements in humans. $\mathrm{Br} \mathrm{J}$ Anaesth 1975; 47: 570-4.
Résumé

Cent vingt patients de statut physique ASA I ou II devant subir utre chirurgie elective ont reç" $0.06 \mathrm{mg} \cdot \mathrm{kg}^{-1}$ de pancuronium durant une anesthésie au thiopental-protoxyde d'azote-enflurane, afin de comparer la capacité de doses équipotentes de néostigmine, de pyridortigmine et d"édrophonium à neutraliser le blocage neuramusculaire intense du pancuronium. On a appliqué une stimulation de train-de-quatre da toutes les douze secondes et la force de la contraction du muscle adducteur du pouce a été enregistrée. Chez les 60 premiers patients, on a laissé la force de contraction se rétablir de façon spontanée jusqu' a ce qu' elle atteigne dix pour ceru de la hauteur initiale de la première convulsion. On a ensuite rêparti, de facon aléatoire. des injections de néostigmine $10.005,0.01,0.02$ ou 0.05 $\left.\mathrm{mg} \cdot \mathrm{kg}^{-1}\right)$, de pyridosrigmine $\left(0.02,0.04,0.1\right.$ ou $\left.0.2 \mathrm{mg} \cdot \mathrm{kg}^{-1}\right)$, ou d'édrophonium (0.1, 0.2. $0.4 \mathrm{ou} / \mathrm{mg} \cdot \mathrm{kg}^{-1}$ ). Dix minutes plus tard, on a établi les relations dose-effet a partir de la mesure de la hatueur de la première contraction (TI). A partir de ces données, on a trokvé que des doses de néostigmine d 0.04 et $0.08 \mathrm{mg} \cdot \mathrm{kg}^{-1}$ étaient équipotentes à celles de 0.2 et 0.38 $\mathrm{mg} \cdot \mathrm{kg}^{-1}$ de pyridostigmine et d̀ celles de $0.54 \mathrm{et} 1.15 \mathrm{mg} \cdot \mathrm{kg}^{-1}$ d'édrophonium respectivement. On a réparti ces doses, de façon aléaroire, chez les 60 patients suivants, mais a un pour cent seulement du rétablissement spontané. Une dose de 0.04 $\mathrm{mg} \cdot \mathrm{kg}$ ' de néostigmine a produit un $\mathrm{Tl}$ de $73 \pm 4$ pour cent (moyenne \pm SEM), et un rapport train-de-quatre (TDQ) de 39 \pm 3 pour cent. Ce résultat était significativement plus élevé que celui obtenu avec $0.2 \mathrm{mg} \cdot \mathrm{kg}^{-1}$ de pyridostigmine $(T)=50 \pm 6$ pour cent $; T D Q=25 \pm 3$ pour cent), et avec $0.54 \mathrm{mg} \cdot \mathrm{kg}^{-1}(\mathrm{TI}$ $=54 \pm 3$ pour cent,$T D Q=17 \pm 2$ pour cent $)$. A des doses plus élevées, $0.08 \mathrm{mg} \cdot \mathrm{kg}^{-1}$ de néostigmine a produit un meilleur rétablissement du $T\}, 83 \pm 3$ pour cent) et du $T D Q(45 \pm 3$ pour cent) que $0.38 \mathrm{mg} \cdot \mathrm{kg}^{-1}(T I=74 \pm 3$ pour cent $)$ ou $1.15 \mathrm{mg} \cdot \mathrm{kg}^{-1}$ d'edrophonium $(T)=71 \pm 4$ pour cent; $T D Q=30 \pm 3$ pour (ent). Nous concluons dionc que la néastigmine est plus efficace que les deux autres agents pour neutraliser le blocage profond du pancuronium. 